\title{
In the Ethics of Strangers: Saul Bellow Drawing Boundaries of No 'M'an's Land
}

\author{
Ramzi Marrouchi \\ Department of English, Faculty of Letters, Arts and Humanities \\ University of Manouba, Tunisia \\ Corresponding Author: ramzi.marrouchi@yahoo.fr
}

Rimeh Saleh Alyahya

Department of English

Princess Nora bint Abdulrahman University, Saudi Arabia

Received: 10/20/2021

Accepted: 2/6/2022

Published: $2 / 24 / 2022$

\begin{abstract}
:
This paper seeks to demonstrate how space in Saul Bellow's Ravelstein (2000) and Humboldt's Gift (1975) is acquainted with the metaphors memory, spiritual journeys and philosophical meditations. Space, in the Bellovian sense, is not local nor is it historical (real); rather, it is fictional, utopian and philosophical. By the "the Boundaries of no 'M'an's Land," the researcher underpins the sublime ideals of Bellow's mental space. By the term "strangers," the researcher refers to Bellow's intellectual heroes who are identified with the metaphors of space. In this concern, two fundamental questions are investigated: a) how should one argue for the idea that metaphors of space are related to memory, spiritual journeys and philosophical meditations? b) what sense can be given to the relationship between the metaphors of space and the ethics of strangers? To unmask these blind spots, the aspects of metaphors are firstly investigated. Second, the relationship between these metaphors and the ethics of strangers are examined. In the light of these primary findings, the conclusion which can be drawn is that the metaphors of space do not only epitomize the quality of American, cultural, aesthetic and philosophical discourse, but also draw imaginary homelands of "strange" intellectuals. Special focus will be given to Ravelstein and Humboldt's Gift. Bellow's other novels and short stories are deployed to support the thesis. The Kantian notions of human welfare and moral worth and the Hegelian assumptions of the phenomenology of spirit are key concepts to illustrate the analysis.
\end{abstract}

Keywords: Boundaries, Humboldt's Gift, Hegel's phenomenology of spirit, Kant's Moral Theory, No 'M'an's Land, Ravelstein, space, strangers, Saul Bellow

Cite as: Marrouchi, R., \& Alyahya, R. S. (2022). In the Ethics of Strangers: Saul Bellow Drawing Boundaries of No 'M'an's Land . Arab World English Journal for Translation \& Literary Studies 6(1) 30-39. DOI: http://dx.doi.org/10.24093/awejtls/vol6no1.3 


\section{Introduction}

We were to travel for another week, a foot, a foot [...] I did not have the remotest idea of where we were [...] I had great trust in Romilayu, the old fellow. For days and days, he led me through villages, over mountain trails, and into deserts, far, far out (Bellow, 1959, p. 7).

Henderson the Rain King claimed once presenting us with his sketch of how the intellectual should feel "at home in the world" (Hegel, 1977, p. 217). Here, this withdrawal in the function of space seems particularly significant since intellectuals are confident of finding themselves at home, in a distinctively sublime way once leaving the ordinary world behind. Bellow called consciousness in this "happy state" a "present living spirit," not only because the subjects feel not alienated from/in the world but also because these subjects are continually living in a happy and Platonic world of metaphors. The immediate implication is that these fictional subjects are not real figures who are living in historical spaces, but they are ideas that are developing through memory, spiritual journeys, and philosophical meditations.

Following this claim, my subject is going to be a discussion of the way a philosopher writes about a poet compared to the way a poet writes about a philosopher. Ironically enough, it will be a discussion of the way "strangers" write about "other strangers." Being imaginary and even mythical figures, in what way do they reflect each other? How can the storyteller bring these strangers together in imaginary homelands?

\section{Poets and Philosophers in Humboldt's Gift and Ravelstein}

Logically this enormous subject will have to be limited. On this view, I am going to investigate only two narratives of Bellow: Humboldt's Gift and Ravelstein. In both texts, space is associated with the metaphors of memory, spiritual journeys and philosophical meditations. Humboldt and Ravelstein are introduced either by an anonymous storyteller or a friend who is supposed to be a poet or a philosopher. There is always someone who should survive to tell the stories of the heroes.

Overtoning a philosophical, moral theory, Bellow likes to open his narratives with spiritual journeys and philosophical meditations. Memory, following this, is the core stone of the building of the process of storytelling. The reader can only be haunted by this enterprise. Ravelstein opens with: "if I had died I would naturally have been released from the promise I had made years ago to write a short description of Ravelstein and to give an account of his life" (Bellow, 2000, p. 230), implying that he was still alive, and he actually wrote an account of his friend. The gesture of writing the life of Ravelstein turns into a philosophical and moral duty. Everything turns into fragmented memories which both resurrect and devalues the dead Ravelstein: "having come near death myself, I don't need to fear the guilt the living often feel about those others- parents, wives, husbands, brothers and friends- in their graves" (p. 230).

Arab World English Journal for Translation \& Literary Studies 
The paradoxical and reciprocal movement from the grave to the earth and back from the earth to the grave does not only alter the function of space but also paves the way for philosophical meditations:

Life would soon be back, and I would occupy my seat in the life train. Death would shrink into its former place at the margin of the landscape. The patient's desire is to crawl or limp or maneuver himself back to the life that proceeded the illness, and to entrench and fortify himself in the old position. (p. 230)

Memory traces the boundaries of life (life-death) as well as the contour of space. The life and death struggle unravels the latter in the periphery and the former at the center. Memory and space, as can be understood interchangeably, provide Ravelstein with some sense of recognition. As a matter of fact, he wants to show that he is a subject, a human being with moral ideals and not a mere living thing. Although he knows that he is a subject (a philosopher and a poet), he needs to convince the reader that death: "death would shrink into its former place at the margin of the landscape" (p. 231), that he is not a merely living creature lacking in the subject hood. What is required for self-recognition is that one should not risk his own life; rather, he should survive even through the writing of his own memories:

Rosamund was determined that I should go on living [...] it was she [...] who has saved me- flew me from the Caribbean just in time, saw me through intensive care, sleeping in a chair beside my bed. When I struggle to breathe she would raise the oxygen mask to swab the inside of my mouth. (p. 225)

Bellow, then, asserts that the most basic ways for a subject to demonstrate its status as a subject to another and hence to achieve recognition for subjecthood is to show that it is not prepared to give up life. Ravelstein innately supports this claim assuming that: "the individual who has risked his life may well be recognized as a person" (Hegel, 1977, p. 114). The assumption behind this may seem confirmed when we read Bellow's vigorous belief in survival as a "categorical imperative" that we must obey with the attitude of a dutiful man following orders, respecting the authority of law without regard to anything else (Bellow, 1976, 1995).

Humboldt scrupulously echoes Ravelstein. Being a mad poet, he develops his moral theory only through memory, spiritual journeys and philosophical meditations. Charles Citrine, the philosopher, is the one who should survive to tell the story of Humboldt: "I was not doing well myself recently when Humboldt acted from the grave, so to speak, and made a basic change in my life $[\ldots]$ he left me something in his will. I came into a legacy" (Bellow, 1975, p. 6). Humboldt "was just what everyone had been waiting for" (p. 1) to bring some change to the world. Assuming that we are not only living in a moral world, but also moral agents par excellence who should die to do something good, Humboldt philosophically reviews history, and considers it to be a "nightmare during which [ one should strive] to get a good night's rest" (p. 4). Enigmatic and philosophical meditations unravel the daunting task of achieving a certain sense of moral and spiritual identity. Humboldt asserts with a mad tone: 
What for? What was I doing? Suppose I found a dime? Suppose I found fifty-cent piece? What then? I do not know what the child's soul had gotten back, but it was back. Everything was melting. Ice, discretion, maturity. What would Humboldt have said to this? (p. 3)

Ambivalent answers are introduced in the form of "strange" ethical norms that highlight Humboldt's most sublime ideals in his cognitive space. One's identity, following this, is to be seen in relationship with being a poet, a philosopher, a historian and a mad man: "the noble idea of being $[\ldots]$ a poet certainly made Humboldt feel at times like a card, a boy, a comic fool" (pp.5-6). Reflecting upon Herzog's terms "if I am out of my mind that's all right with me" (Bellow, 1964, p. 1), Humboldt behaves like an eccentric and a comic subject, pondering upon life and death, memory and space, ethics and philosophy to satisfy certain great questions. His awareness of the fact that ruinous disorders follow us disquietly to our graves, he strikingly attempts to negate space, memory, meditations and spiritual journeys. Charles Citrine, the storyteller of his stories, sums up his fate claiming that, "he [Humboldt] tried drugs and drink. Finally, many courses of shock treatment had to be administered. It was, as he saw it, Humboldt versus madness. Madness was a whole lot stronger" (Bellow, 1975, p.6).

In To Jerusalem and Back (1976) The Bellarosa Connection (1989) It All Adds Up: From the Dim Past to the Uncertain Future (1995) Mr. Sammler's Planet (1970) and many other stories, space seems to be reduced into memories and meditations which generate moral and ethical norms of strange intellectuals. In this sense, 'Jerusalem' is a holy space which ironically never quench our thirst with a spiritual peace. The space unfortunately turns to be a metaphor of never-ending conflicts and misunderstandings. Sammler's 'planet' is a utopian territory of no man's land. Curiously enough, he begins drawing his imaginary world exactly when the storyteller of Jerusalem finds his way out from the holy land, and, then, his planet unexpectedly remained empty. 'The dim past' and 'the uncertain future' in Bellow's latest essay qualify 'Sammler's planet' by openness and vividness that devoid it from any sense. In the light of this, the flares of hope of a certain identity within the boundaries of memory and the metaphors of space appear to be illusory triumphs. The fictional subjects keep questioning the very notions of space, memory, author, authority, philosophy, history, self, other, life, death in a way they turn to be others and usurpers. Bellow, to make sure, does imply that these subjects are not only strange, unrecognized moral legislators of moral and ethical laws, but also agents of these laws. Space as a metaphor, to Bellow's mind, should enhance and further aggravate the necessity of the switch from the lack in subjecthood, to borrow the term from Hegel, to the full belonging and identity.

Bellow never seemed to be reluctant to relate the metaphors of space to the recognition of one's moral and ethical insights. One way of understanding this point is to override man's sense of ethics and morality. In this respect, supporting the idea that we have moral responsibility to maximize good willing and morality in the world or even make those close to us maintain a good will becomes a Bellovian priority (Hill, 2002, p. 53). Therefore, he "repeatedly insists that each person's responsibility to others is to respect their moral and legal rights and, beyond that, to promote their happiness [and their] moral goodness" (p. 51). Bellow fictionally justifies his moral and ethical constructivist theory by reflecting upon Hume's humanistic ideals that "morality would be useless if it had no such direct influence upon what people do" (Mackie, 2001, p. 3), assuming 
AWEJ for Translation \& Literary Studies Volume, 6 Number 1. February 2022

that he is not answering any question of what we ought to do or even what we have to do but curiously showing innate moral faculties implanted in human beings by their creator.

Humboldt is a good example of this moral speculation. Charles Citrine states that:

A world of categories devoid of spirit waits for the life to Return. Humboldt was supposed to be an instrument of this revival. This mission or vocation was reflected on his face. The hope of new beauty. The promise, the secret of beauty. (Bellow, 1975, p. 17)

Redeeming the world, as home to think with Hegel, from its impurities, Humboldt aestheticizes it, and turns it into an intellectual picture through his meditations. His dreams to achieve his mission, as he believes, will not see life once neglecting the "hope of a new sublime beauty." He reflects upon:

William Blake at Felpham, Milton's Eden, Plato's Timoeus, Proust on Combray, Virgil on farming, Marvell on gardens [...] Martin Sewell at Princeton, Henry James in Damascus [...] Balzac in France [...] Marx's portrait of Louis Bonaparte [...] Hegel's world historical individual. (pp. 17-18)

The world-home should be a theatre, and we -inhabitants- should act perfectly upon its stage. Poetry is the most sublime language with which we need to communicate. Humboldt retreats from the ordinary world as Citrine interestingly informs:

Poet, thinker, problem drinker, pill-taker, man of genius, manic depressive, intricate schemer, success story [teller], he once wrote poems of great wit and beauty, but what had he done lately? had he uttered the great words and songs in him? he had not. Unwritten poems were killing him. (p. 25)

He celebrates his Platonic world. He does not intend to be solitary, but he interestingly means to be active in life, to theorize for a better moral world. The unwritten poems are possible categorical imperatives yet to come. Life, to Humboldt's sense, has lost its ability to arrange itself. For this reason, it has to be arranged. The world should be brought home, and one must feel satisfaction in it. Building upon the Hegelian thought, Humboldt reminds that "the aim of knowledge is to divest the objective world that stands opposed to us of its strangeness, and, as the phrase is, to find ourselves at home in it: which means no more than to trace the objective world back to the notionto our inner most self" (Stern, 2002, p. 12). In this vehement desire to achieve some sort of moral and ethical harmony with the world, Bellow arguably points that this is the duty of the intellectuals and the philosophers. Humboldt, then, as a philosopher and a poet, should not only reflect upon these issues philosophically but also aesthetically in order to achieve such a peace (p. 17). One way of taking the further is

What a human being is -I always had my own odd sense of this. For I did not have to live in the land of horses, like Dr. Gulliver, my sense of human kind was strange enough without travel. In fact, I travel not to seek foreign oddities but to get away from them. I was drawn also to philosophical idealists because I was perfectly sure that this could not be it, Plato in the myth of Er confirmed my sense that this was not my first time around. We had all been 
here before and would presently be here again. There was [...] no other place. (Bellow, 1975, p. 89)

Journeying, not in Bellow's way to 'Jerusalem,' but in Henderson's manner, “the soul is supposed to be sealed by oblivion before its return to earthly life. Was it possible that my oblivion might be slightly defective (p. 90)? Humboldt, to be sure, is lost in his Platonic ethics since there is no other place where to travel and do something good.

Ravelstein aggravates these 'strange' ethics by deploying an escapist strategy. He shifts all the time from telling his own story to acquainting the reader with the oddities of history. The fictional and the historical overlap. Space turns to be another metaphor for other strange ethics, "for I have promises to keep/And miles to go before I sleep/For I have recipes to bake/And far to go before I wake" (p. 114). The trip takes place between sleeping and awakening, promises to bring some change to the world and to do something good are kept in the spirit of the speaker. Getting up from his sleep, he will surprisingly find himself unified with his Platonic 'home.' The trip ends up and all the secrets are revealed and the reader is brought back once again to the cognitive world of the storyteller. While the fictionality of the trip is highlighted through poetical devices, the 'history of the story' is introduced in the form of ethical and philosophical interrogations as he keeps reflecting upon the very notions of suicide, boredom, history of wars, Jewishness and Zionism.

\section{The Metaphor of Space and the Boundaries of Strangers:}

The reader is highly invited to think philosophically with these subjects. Consequently, being part of this enterprise, it is the purpose of the researcher, therefore, to investigate the possible relationships between meditations, journeys and memory, on the one hand, and the ethics of strangers, on the other hand. Accordingly, one reader/thinker, as Robert Stern aptly reminds "should step back and apply himself reflectively [in a Hegelian manner] and ask how it is the problem has arisen in the first place; once we see that the problem has its source in a set of onesided assumption. If we can overcome that one-sidedness then the problem will simply dissolve and we escape the oscillation between the one satisfactory stance and its equally unsatisfactory opposite" (2002, p. 12). What logically comes out from this say is that while mapping space in the Bellovian context, one should not only investigate its social connotations, but also pause for a moment and reflect upon their cognitive and metaphorical aspects.

Zygmunt Bauman aptly reminds us that cognitive and philosophical spacing, though not objective, moral and aesthetic, yet they are human made. The misunderstanding of the other stems not from conflicting interests but rather from the ignorance of the cognitive maps of the other. That to live is to live with the other, to grasp his physical space intellectually. By the same token Ravelstein draws the world, home, an intellectual picture that sums up man's ethical boundaries. Humboldt, echoing Herzog, posits the idea from a poetical perspective, assuming that only poetry which reduces distance between the intellectuals. Alfred schutz and Thomas Luckmann aggravate the structures of the life-world, the necessity of mutual understanding through the metaphor of space assuring that: 
I simply take it for granted that other men also exist in this/my world, and indeed not only in a bodily manner like and among other objects, but rather as endowed with a consciousness that is essentially as mine [...] they, my fellow men, experience their relations which reciprocally include in a way that is similar, for all practical purposes, to the way in which I experience them. (Lackmann, 1974, pp. 4-5)

Henderson translates these words by sacrificing his life to save the king of the Arnewi tribe in Africa: "your majesty, move over and I will die beside you. Or else be me and live; I never knew what to do with my life anyway [...] I will die anyway" (1957, p. 262). The sacrifice of one' life is a way of experiencing other's sufferings and turning their experience into a shared feeling.

The metaphor of space becomes a problem of knowledge. American boundaries, to Bellow's mind, should be understood interchangeably with the knowledge of the other. One may say that this happens as the distance between me and the other becomes so huge, and when I have no shared biography with the other. To quote Bauman again:

The farther away [we] are from the intimacy pole [the sphere of togetherness], the more other humans become strangers (until, at the anonymity extreme, they vanish from view altogether). Of strangers, we know too little to engage in $[\ldots]$ any interaction. The 'strangeness' of strangers means precisely our feeling of being lost, of not knowing how to act and what to expect, and the resulting unwillingness of engagement. (2007, p. 149)

Humboldt turns to be a mad poet because he fails to recognize the world around him. The other, for him, is not human at all since "humans who inhabit in that space do not have identities of their own, no personal identities, $[\ldots]$ they derive their identities from [the nowhere of space and the nothing of knowledge]" (p. 149). Ravelstein assumes that the other will not understand his philosophy of poetry, and that he will live and die strange among other unknown strangers. As the phrase goes, death, or the too late consciousness, that comes only after death, is the sole salvation to the problem of knowledge and cognitive spacing since the other will unexpectedly and satirically recognize both Humboldt and Ravelstein only after their deaths.

Herzog describes the other as hell. Any possibility of meeting with him/her turns into chaos since there are no shared intellectual and ethical grounds between them. Being a stranger to the ethics of the other, Herzog vehemently attacks the enemies of life stating: "let the enemies of life step down [...] let each man now examine his heart [...] let us lie down, men women, and children, and cry. Let life continue -we may not deserve it, but let it continue," (1964, p. 67) Henderson illustrates Herzog: "I must not live in the past, it will ruin me [...] I was telling the world that it was a pig. I must begin to think how to live" (p. 242). Again, "I put my list to my face and looked at the sky, giving a short laugh and thinking, Christ! What a person to meet at this distance from home. Yes travel is advisable. Travel is mental travel" (1959, p. 142). The ethical boundaries stop the social space and the possibilities of meeting between these strangers since we find: on the other 
side of the boundary [only] stretched fallow waste, semantic void and wilderness: the intellectually alien world inhabited by faceless bodies. The bodies could cross the frontier, but the rules of coexistence stayed at home and could not survive the trespassing. Humboldt was never able to cross the boundaries of the other, and Ravelstein faces death, his ultimate fate, as the only solution to the misunderstanding of the world-home. Blurring space, accordingly, ends up by being blurring memory and going through philosophical and spiritual journeys.

Humboldt informs that it is best not to meet strangers at all. This, indeed, should be carried out through the art of mismeeting. Humboldt, the unrecognizable poet, is unrecognized by the others and even by his friend Charles Citrine as he is writing strange poems and introducing a strange philosophy. Ravelstein lived and died as an alien. His life story is related through an anonymous storyteller. His intellectual readings of history and philosophy make of him a strange man that is hardly understood by the others. Humboldt and Ravelstein in Bauman's words are: "neither neighbors nor aliens. Or rather- confusingly, disturbingly, terrifyingly- they are (or may be- who knows?) both. Neighborly aliens. Alien neighbors. In other words, strangers" (2007, p. 153). They are inhabitants of no man's land, holders of strange ethics, ambivalent subjects, wise philosophers, mad poets, strong believers in mankind and unrecognized legislators of the world. Charles Citrine never meets Humboldt, and the whole story comes like a dream, like Humboldt's poems, in Citrine's way:

I knew that Humboldt would soon die because I had seen him on the street two months before and he had death all over him. -He did not see me [...] every time I saw him I was terribly moved, and cried in my sleep.- Once I dreamed that we met at Whelan's Drugstore on the corner of sixth and eighth Greenwich Village [...] I burst into tears. I said, "Where have you been? I thought you were dead" [...] I could not get more out of him, and I wept with happiness. Of course it was only a dream such as you dream if your soul is not well. My waking character is far from sound [...] and all such things must be utterly clear to the dead $[. .$.$] out in Chicago Humboldt became one of my significant dead [...] people doing$ articles, academic thesis, and books wrote to me or flew in to discuss Humboldt with me. And I must say that in Chicago Humboldt was a natural subject of reflection. (Bellow, 1957, pp. 7-9)

Ravelstein overtones the same story:

In his own way Ravelstein tried to protect me from poring over the works of the thinkers he most admired. He ordered me to write this memoir, yes, but he didn't think it was necessary for me to grind away at the classics of Western thought. But for the purposes of a short biography I understand him well enough, and I agreed that it should be done by someone like me. - Furthermore, I am a great believer in the power of unfinished work to keep you alive [...] Ravelstein, dressing to go out, and I go back and forth with him while trying to hear what he is saying. The music is pouring from his hi-fi [...] he loses himself in sublime music, a music in which ideas are dissolved, reflecting these ideas in the form of feeling. He carries them down into the street with him [...] Ravelstein looks at me, laughing with pleasure and astonishment, gesturing because he can't be heard in all this

Arab World English Journal for Translation \& Literary Studies 
AWEJ for Translation \& Literary Studies Volume, 6 Number 1. February 2022

bird-noise.- You don't easily give up a creature like Ravelstein to death. (Bellow, 2000, pp. 231-233)

Humboldt, Ravelstein and Citrine appear to be actors and skilled playwrights at the same time. They firmly suggest that we are all players, traveling players carrying our plays with us wherever we go. The cognitive space, the spiritual journeys and the philosophical meditations are the stage or the ground of playing. The purpose of their play is to make the 'other' know about the strangeness of their ethics, and that: "morality which always guided us and still guides us today has powerful, but short hands. It now needs very, very long hands indeed" (Bauman, 2007, p. 218).

\title{
4. Conclusion
}

The ethics of strangers have been proved to be the norms of morality of intellectuals in modern America. The concepts of space and boundaries have been proved to be related to these ethics. As a matter of fact, the researcher has attempted to show how and why Humboldt and Ravelstein, who are respectively a poet and a philosopher, strive to resist the ethics of amorality in modern America and establish a world home in the Hegelian way. The researcher was not only limited to the investigation of the cases of Humboldt and Ravelstein, but also the study of other examples in Bellow's fictional world. Several and interesting overaps between Bellow's heroes and stories seemed to be significant in the argumentation. To achieve this, these heroes established imaginary journeys which refer to space and boundaries as concepts. Memory, following this, becomes the core stone of the building of the process of the storytelling as it traces the boundaries of life (life-death) as well as the contour of the moral world in modern America. Bellow recommends through his strange heroes that to achieve a moral and ethical world, where we live happily, one should add value and sense to the space, boundaries and things.

\begin{abstract}
About the Authors:
Dr. Ramzi Marrouchi, the author of Images of Madness in Henderson the Rain King and Herzog, (Scholars Press, 2019), and Functional English for Potential Achievers, (Scholars Press, 2020), Life and Fiction in Defoe's Moll Flanders (BP International, 2021). He lectured in different universities in Tunisia and Saudi Arabia. He participated at several international interdisciplinary conferences in Tunisia, Saudi Arabia, Malaysia, Indonesia, Singapore, Britain, the USA and Morocco. His fields of interest are Jewish American fiction, deconstructionism and theories of texts. ORCID ID: https://orcid.org/0000-0002-1287-2143
\end{abstract}

Dr. Rimah Alyahya procured her Ph.D. in English Literature from Princess Nora University in 2005. She became the Chairperson of the English and Translation Department in 2006 and then the first female Vice-Rector of the Women's Campus in Prince Sultan University. She was then appointed as the first female Deputy Minister for Private Higher Education and is now a member of the Saudi Shura Council. 
AWEJ for Translation \& Literary Studies Volume, 6 Number 1. February 2022

In the Ethics of Strangers: Saul Bellow Drawing Boundaries

Marrouchi \& Alyahya

\section{References}

Bellow, S. (1959). Henderson the Rain King. New York: Fawcett World Library.

Bellow, S. (1964). Herzog. New York: Foucault world Library.

Bellow, S. (1976). Mr. Sammler's Planet. New York: Fawcett World Library.

Bellow, S. (1995). It All Adds Up: From the Dim Past to the Uncertain Future. New York: Penguin.

Bellow, S. (1975). Humboldt's Gift. New York: Viking Press.

Bellow, S. (2000). Ravelstein. New York: Penguin Books.

Hegel, G.F.W. (1977). The Phenomenology of Spirit. Oxford: Oxford University Press.

Hill, T. E. Jr. (2002). Human Welfare and Moral Worth. Oxford: Oxford University Press.

Mackie, J.L. (2001). Hume's Moral Theory. New York: Routledge.

Stern, R. (2002). Hegel and the Phenomenology of Spirit. London: Routledge.

Bauman, Z. (2007). Postmodern Ethics. Malden: Blackwell Publishing. 